1987

Dexamethasone and the serious head injury

Rashid Jooma

Follow this and additional works at: https://ecommons.aku.edu/pakistan_fhs_mc_surg_neurosurg

Part of the Neurology Commons, Neurosurgery Commons, and the Surgery Commons 


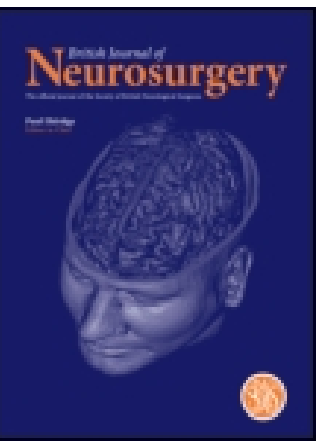

British Journal of Neurosurgery

ISSN: 0268-8697 (Print) 1360-046X (Online) Journal homepage: https://www.tandfonline.com/loi/ibjn20

\section{Dexamethasone and the Serious Head Injury}

\section{Rashid Jooma}

To cite this article: Rashid Jooma (1987) Dexamethasone and the Serious Head Injury, British Journal of Neurosurgery, 1:4, 400-403, DOI: $10.3109 / 02688698708999630$

To link to this article: https://doi.org/10.3109/02688698708999630

央 Published online: 06 Jul 2009.

Submit your article to this journal

LII Article views: 8 
start of a disease spectrum with cervical spondylosis as the end product, it is important to point out that, in Jeffreys' series, $30 \%$ of patients had sufficient extruded disc material to play an important role in compression of the cord in addition to that of osteophytic protrusion.

The role of trauma in the development of CSM is interesting; Jeffreys ${ }^{7}$ found that $10 \%$ gave a history of a neck injury in the past, $8 \%$ experienced a neck injury which precipitated a neurological decline and $16 \%$ gave a history of both, i.e. approximately $44 \%$ experienced a neck injury at some time. Nurick found that $14 \%$ experienced an injury in the month prior to admission and which had frequently precipitated the final decline. It would seem that the past neck injury may have contributed to the degenerative disease and the precipitating injury in some way further compromised a spinal cord already in jeopardy.

The role of subluxation in the evolution of CSM remains problematical. Jeffreys ${ }^{7}$ found subluxation to be present in 3\% whereas Nurick ${ }^{4}$ found that not only did this radiological sign occur in $28.7 \%$ but that it tended to be associated with increasing disability. One possible explanation of this discrepancy may lie in the fact that in the former series the patients were more disabled and possibly had more advanced spondylosis such that their cervical spines were more rigid and less able to sublux than those in Nurick's series.

Finally there is the evidence that many patients improve greatly and rapidly once the compressive agent has been removed, particularly after anterior cervical decompression and fusion ${ }^{7,8}$. Whereas one accepts that decompression successfully carried out could improve cord blood flow and relieve cord stretching the theory most likely to explain a myelopathy is compression of the spinal cord; provided that one also allows that in any compression there must be an element of local ischaemia in the cord at the site of compression, caused by the compressing agent 'squashing' the vascular bed at that point.

RICHARD JEFFREYS

\section{References}

1 Hughes JT, Brownell B. Cervical spondylosis complicated by anterior spinal artery thrombosis. Neurol (Minneap) 1964; 14:1073-7.

2 Hughes JT. Pathology of the Spinal Cord. 2nd ed. London: Lloyd-Luke, 1978.

3 Frykholm R. Cervical nerve root compression resulting from disc degeneration and root-sleeve fibrosis. Acta Chir Scand 1951: Suppl. 160.

4 Nurick S. The pathenogenesis of the spinal cord disorder associated with cervical spondylosis. Brain 1972; 95:87-100.

5 Adams CBT, Logue V. Studies in cervical spondylotic myelopathy. 2. The movement and contour of the spine in relation to the neural complications of cervical spondylosis. Brain 1971; 94:569-86.

6 Barnes MP, Saunders $M$. The effect of cervical mobility on the natural history of cervical spondylotic myelopathy. J Neurol Neurosurg Psychiat 1984; 47:17-20.

7 Jeffreys RV. The surgical treatment of cervical myelopathy due to spondylosis and disc degeneration. J Neurol Neurosurg Psychiat 1986; 49:353-61.

8 Phillips DG. Surgical treatment of myelopathy with cervical spondylosis. J Neurol Neurosurg Psychiat $1973 ; 36: 879-84$.

\section{Dexamethasone and the Serious Head Injury}

The serious head injury remains a grave medical problem with a mortality of about $40 \%$ and a good outcome in only $20 \%$ in most large series round the world ${ }^{19}$. Physical disruption of neural tissue, ischaemia and oedema are the pathologic substrates in the diffuse brain injury ${ }^{21}$ and therapy aimed at attenuating the effects of these on intracranial pressure has been the major preoccupation of those caring for head injured patients. Thus, after the demonstration of a dramatic decrease in cerebral oedema associated with brain tumours by dexamethasone ${ }^{11}$, it was not surprising that the use of this agent in head injuries rapidly gained widespread currency. It is now recommended by most standard textbooks and almost universally used by physicians other than neurosurgeons. Amongst the latter, as so often happens in medicine, enthusiasm has been tempered by experience.

Experimental verification of the beneficial effects of steroids on post-traumatic cerebral oedema was sought soon after their clinical introduction. Various animal models and protocols were used but conclusions were varied. 
Blinderman et al. ${ }^{3}$ demonstrated a reduction in oedema induced by intracarotid injection of vegetable oil when Solumedrol was infused during the procedure. Lippert et al. ${ }^{17}$ produced oedema in the brain of the dog by implanting psyllium seed and began cortisone on the day of operation. Their conclusions were equivocal. Long et al. ${ }^{18}$ on the other hand found reduction in psyllium induced oedema in the rabbit pre-treated with dexamethasone.

Clasen et al. ${ }^{5}$ produced oedema in monkeys by freezing through the intact skull but found no benefit of treatment with prednisolone, while Benson et al. ${ }^{2}$ were similarly disappointed when steroids did not significantly lessen laser produced oedema in rats. The cold injury model was modified to produce local cooling of the exposed dura or brain in cats and a definite decrease in cerebral oedema was observed by Pappius \& $\mathrm{McCann}^{23}$ and Maxwell et al. ${ }^{20}$ but not by Dick et al. ${ }^{9}$ or Nelson ${ }^{22}$. Kobrine \& Kempe $^{16}$ used a model of acceleration-deceleration injury in monkeys and found traumatic brain swelling to be significantly less in the treated as compared to control groups with extension of survival as well. On the other hand the acute head injury produced in cats with a humane stunner by Tarnheim \& McLaurin ${ }^{27}$ was not affected by dexamethasone therapy. All these models have concentrated on cerebral oedema and the relevance of this to the clinical situation is unclear, particularly as the results of clinical trials have not been consistent.

The earliest trials were uncontrolled, such as that by Sparacio et al. ${ }^{26}$ who showed a superior outcome in patients with diffuse brain injury treated with high dose methylprednisolone when compared to the author's previous experience but no benefit to those with focal lesions. Looking at patients with traumatic decerebration Gutterman et al. ${ }^{14}$ concluded that steroids did not improve the percentage or quality of survival from traumatic decerebration and indeed may have had a deleterious effect. Hoyt $^{15}$ reported on an unblinded study of 16 patients treated with placebo and dexamethasone with little difference in mortality. A larger number of patients were entered in a similar trial by Alexander ${ }^{1}$ with an 8-year study of 110 cases of closed head injury equally divided between placebo and dexamethasone groups. $\mathrm{He}$ found "that the use of steroids in the acutely injured patient, though probably not harmful, is of no real help".

Faupel et al. ${ }^{10}$ reported the first double blind study comparing placebo, low dose dexamethasone and high dose dexamethasone in patients with severe closed head injury. There was a significant reduction in mortality in the treated patients (57\% in placebo group versus $24 \%$ in the combined steroid groups). However, it must be noted that in the treated group $25.4 \%$ of the survivors were vegetative compared to $3.6 \%$ of the placebo group and $11.9 \%$ were severely disabled compared to $7.1 \%$ in the control group. Thus, benefit of steroid in this trial is less clear when death or poor outcome is compared to a good or moderate outcome. A trial of similar design was reported by Gobiet et al. ${ }^{12}$ and a significant reduction in mortality was claimed. This trial has been criticised on statistical grounds and because of incomplete data ${ }^{7}$. Indeed, uncritical acceptance of data such as presented in these two trials had given dexamethasone an authenticity in head injury management it ill-deserved. Gudeman et al. ${ }^{13}$ in 1979 noted that over the past 10 years steroids had come to be used routinely in head injury "despite a disconcerting lack of its beneficial influence on outcome or on intracranial pressure in such patients". Their study of 20 cases not only failed to show benefit, there was in addition a high incidence of gastric haemorrhage and hyperglycaemia.

Over the past 8 years four prospective double-blind controlled trials of high dose dexamethasone therapy in head injuries have been publicised. Cooper et al. ${ }^{7}$ studied 76 patients and found no difference in outcome between the treated and placebo group, while infectious complications were more frequent in the steroid group. The real importance of their study was the availability of post-mortem data for 32 of the 39 patients who died and this data allowed the authors to conclude that $90 \%$ of the deaths could not be influenced by steroid therapy being due either to severe brain 
injuries with parenchymal haemorrhage and tissue disruption, recurrent haematomas or medical complications. Saul et al. ${ }^{25}$ studied 100 comatose patients and there was no significant difference in outcome between the two groups though in those treated patients responding early, a higher incidence of good recovery was observed. Braakman et al. ${ }^{4}$ entered 161 patients into their trial and found no difference in survival or outcome in the whole group or in any sub-group with varying severity of brain damage. An increase in pulmonary infection in the steroid group was observed. Dearden et al. ${ }^{8}$ reported on 130 severely head injured patients and found no advantage of high dose dexamethasone on intracranial pressure (ICP) trends or clinical outcome. Indeed, treated patients with raised ICP fared worse. They also confirmed the hyperglycaemia shown to be more frequent in steroid treated patients in previous trials.

During the last few years attention has focussed on the metabolic consequences of severe head injuries and a profound traumatic response identified by increased energy expenditure, a negative nitrogen balance, hypoalbuminaemia and weight loss has been found ${ }^{28}$. The metabolic response has been estimated to be similar to that in patients with burns of $20-40 \%$ of body surface ${ }^{6}$. This catabolic state is accentuated by steroid administration and in a study of 20 head injured patients ${ }^{24}$ randomised to methylprednisolone or no steroid, the patients receiving steroid had a $30 \%$ higher excretion of nitrogen in the first 6 days after injury. Immunosuppression, evidenced by a lower total lymphocyte count and a higher incidence of infections was present in the treated group; hyperglycaemia requiring insulin was more common in those patients ${ }^{24}$. Hyperglycaemia has been shown to worsen the prospects of a recovery of ischaemic neurones in stroke by increasing local lactic acid concentration and it has been suggested that the same may happen in head injuries. Raised intracranial pressure causes ischaemia particularly in the traumatised areas of brain and steroids may, by inducing hyperglycaemia and its attendant neuronal lactacidosis, be detrimental to recovery. If this hypothesis is confirmed, steroids may be positively contraindicated in head injuries.

Thus a review of the literature clearly shows an emerging consensus that dexamethasone confers no benefit to the seriously head injured patient and may in fact be harmful. The four double blind trials quoted above all contained sufficiently large sample sizes and were methodologically sound enough to make their combined conclusion unassailable. It is unlikely that any further trial will show a contrary result.

\section{RASHID JOOMA}

\section{References}

1 Alexander E, Jr. Medical management of closed head injuries. Clin Neurosurg 1972; 19:240-50.

2 Benson VM, McLaurin RL, Foulkes EG. An experimental model with evaluation of dexamethasone. Arch Neurol 1970; 23:179-86.

3 Blinderman EE, Graf CJ, Fitzpatrick T. Basic studies in cerebral oedema: its control by a corticosteroid (Solu-Medrol). J Neurosurg 1962; 19:319-24.

4 Braakman R, Schouten HJA, Blaauw-Van Dishoeck M, et al. Megadose steroids in severe head injury. Results of a prospective double blind clinical trial. J Neurosurg 1983; 58:326-30.

5 Clasen RA, Cooke PM, Pandolfin S, et al. Steroid Antihistaminic therapy in experimental cerebral oedema. Arch Neurol 1965; 13:584-92.

6 Clifton GL, Robertson CS, Grossman RG, et al. The metabolic response to severe head injury. J Neurosurg 1984; 60:687-96.

7 Cooper PR, Moody S, Kemp WK, et al. Dexamethasone and severe head injury. A prospective doubleblind study. J Neurosurg 1979; 51:307-16.

8 Dearden NM, Gibson JS, McDowell DG. Effect of high dose dexamethasone on outcome from severe head injury. J Neurosurg 1986; 64:81-8.

9 Dick AR, McCallum ME, Maxwell JA. Effect of dexamethasone on experimental brain oedema in cats. J Neurosurg 1976; 45:141-7.

10 Faupel G, Renien HJ, Muller D, et al. Double-blind study on the effects of steroids on severe closed head injury. In: Pappius HM, Feindel W, eds. Dynamics of Brain Oedema. Berlin: Springer Verlag, 1976; 337-43.

11 Galicich JH, French LA. Use of dexamethasone in the treatment of cerebral oedema resulting from brain tumours and brain surgery. Am Pract 1961;12:169-74.

12 Gobiet W, Bock WJ, Liesegang J, et al. Treatment of acute cerebral oedema with high dose dexamethasone. In: Becks JWF, Bosch DA, Brock M, eds. Intracranial Pressure III. Berlin: Springer Verlag, 1976; 231-5.

13 Gudeman SK, Miller JD, Becker DP. Failure of high dose steroid therapy to influence intracranial pressure 
in patients with severe head injury. J Neurosurg 1979; 51:301-6.

14 Gutterman P, Shenkin HA. Prognostic features in recovery from traumatic decerebration. J Neurosurg $1970 ; 32: 330-5$.

15 Hoyt HJ, Goldstein FP, Reigel DH, et al. Clinical evaluation of highly water-soluble steroids in the treatment of cerebral oedema of traumatic origin. Clin Pharmacol Ther 1972; 13: 141 [abstract].

16 Kobrine AI, Kempe LG. Studies in head injury. Part II: effect of dexamethasone on traumatic brain swelling. Surg Neurol 1973; 1:38-42.

17 Lippert RG, Svien HJ, Grindlay JH, et al. The effect of cortisone on experimental cerebral oedema. J Neurosurg 1960; 17:583-9.

18 Long DM, Hatrman JF, French LA. The response of experimental cerebral oedema to glucosteroid administration. J Neurosurg 1966; 24:843-55.

19 Lyle DM, Pierce JP, Freeman EA. Clinical course and outcome of severe head injury in Australia. J Neurosurg 1986; 65:15-8.

20 Maxwell RE, Long DM, French LA. The effects of glucosteroids on experimental cold induced brain oedema. J Neurosurg 1971; 34:477-88.
21 Mendelow AD, Teasdale GM. Pathophysiology of head injuries. Br J Surg 1983; 70:641-50.

22 Nelson SR. Effects of drug on experimental brain oedema in mice. J Neurosurg 1974; 41:193-9.

23 Pappius HM, McCann WP. Effects of steroids on cerebral oedema in cats. Arch Neurol 1969; 20:207-16.

24 Robertson CS, Clifton GL, Goodman JC. Steroid administration and nitrogen excretion in the head injured patients. J Neurosurg 1985; 63:714-8.

25 Saul TG, Ducker TB, Salcman M, et al. Steroids in severe head injury. A prospective randomized clinical trial. J Neurosurg 1981; 54:596-600.

26 Sparacio RR, Lin TH, Cook AW. Methylprednisolone sodium succinate in acute craniocerebral trauma. Surg Gynecol-Obstet 1965; 121:513-6.

27 Turnheim PA, McLaurin RL. Effect of dexamethasone on cerebral oedema from cranial impact in the cat. J Neurosurg 1978; 48:220-7.

28 Young B, Ott L, Norton J, et al. Metabolic and nutritional sequelae in the non-steroid treated head injury patient. Neurosurgery 1985; 17: 784-91. 